\title{
UPAYA MENINGKATKAN HASIL BELAJAR ILMU PENGETAHUAN ALAM ( IPA) DENGAN MENGGUNAKAN MODEL PEMBELAJARAN KOOPERATIFTIPE THINK PAIRS SHARE PADA PESERTA DIDIK SDN 2 LANGKAI PALANGKARAYA TAHUNPELAJARAN 2017/2018
}

\section{Oleh : Yossi Wulandari*Dr. Diplan, M.Pd}

\begin{abstract}
ABSTRAK
Penelitian ini bertujuan untuk (1) mendeskripsikan aktivitas belajar peserta didik dalam pembelajaran IPA dengan menggunakan model Kooperatif Tipe Think Tpairs Share (2) mengetahui peningkatan hasil belajar IPA peserta didik dengan menggunakan model Kooperatif tipeThink Pairs Share .

Bentuk penelitian kelas yaitu PTK. Subjek penelitian adalah seluruh peserta didik kelas V SDN-2 Langkai Palangkaraya berjumlah 15 orang peserta didik yang terdiri dari 8 orang laki-laki dan 7 orang perempuan, analisis menggunakan kuantitatif dan kualitatif.

Hasil penelitian menunjukkan bahwa: (1) aktivitas belajar IPA kelas V SDN-2 langkai Palangkaraya dengan menggunakan model Kooperatif TipeThink Pairs Share berkategori baik atau aktif, (2) terdapat peningkatan hasil belajar IPA menggunakan model Kooperatif tipe think pairs share pada peserta didik kelas V SDN-2 Langkai Palangkaraya Tahun Pelajaran 2017/2018. Hal ini dibuktikan dari data awal rata-rata $(56,66)$, mengalami peningkatan siklus I $(67,33)$ dan siklus II $(80,33)$.
\end{abstract}

Kata Kunci : Hasil Belajar, IPA, Kooperatif tipe Think Pairs Share.

\section{PENDAHULUAN}

Pendidikan merupakan upaya untuk memperbaiki suatu tingkah laku seseorang dengan suatu pengajaran atau latiahan dalam berbagai macam suatu kegiatan dalam kehidupan sosial. Selama ini pemerintah berusaha memberikan perhatian terhadap setiap masalah yang terjadi dalam pendidikan seperti tertuang dalam Undang-Undang

Republik Indonesia nomor 20 tahun 2003 tentang Sistem Pendidikan
Nasional (Sistem Pendidikan Nasional 2003 : 3) menyatakan bahwa : Pendidikan Nasional berfungsi mengembangkan kemampuan dan membentuk watak serta bermartabat dalam rangka mencerdaskan kehidupan bangsa, bertujuan berkembangnya potensi peserta didik agar jadi manusia yang beriman dan bertakwa kepada tuhan yang Maha Esa berakhlak mulia, sehat berilmu, cakap, kreatif, mandiri dan menjadi warga negara yang demokratis serta bertanggung jawab. 
Pendidikan formal yaitu dengan mengikuti jenjang sekolah. Sekolah merupakan salah satu cara dalam memperoleh pendidikan yang lebih layak. Namun semua itu berawal dari lembaga pendidikan yang dasar yaitu Sekolah Dasar (SD). Mata pelajaran IPA sangat memberikan pengetahuan yang luas tentang alam semesta, serta teknologi yang berkembang sampai saat ini. Keberhasilan suatu pembelajaran sangatlah erat kaitannya dengan model untuk menunjang keberhasilan dalam proses belajar mengajar. Namun dalam memilih penggunaan model harus disesuaikan dengan tujuan pembelajaran dan materi yang diajarkan.

Berdasarkan hasil observasi yang dilakukan peneliti pada peserta didik kelas V SDN- 2 Langkai Palangka Raya. Peneliti mendapatkan fenomena pada saat proses pembelajaran IPA sering mengelami kesulitan terutama dalam pencapaian hasil belajar disebabkan minat peserta didik terhadap pembelajaran IPA sangatlah kurang. Minat yang kurang membuat peserta didik merasa bosan, tidak terlibat dalam pembelajaran, tidak aktif, dan kurang termotivasi. Adapun aktivitas peserta didik lebih suka mengerjakan LKS. Sehingga membuat nilai harian peserta didik rendah dan dibawah Kriteria Ketuntasan Minimal (KKM) yang telah ditentukan oleh pihak sekolah yaitu 70 . Dari 15 peserta didik 60\% ( 9 orang) peserta didik mendapat nilai dibawah KKM 70 yang sudah ditentukan dan hanya $40 \%$ (6 orang) yang mencapai KKM.dari fenomena terjadi maka peneliti tertarik untuk melakukan penelitian dengan judul "Upaya Meningkatkan Hasil Belajar Ilmu Pengetahuan Alam (IPA) dengan Menggunakan Model Pembelajaran Kooperatif Tipe Think Pairs Share pada Peserta Didik Kelas V SDN-2 Langkai Palangka Raya tahun 2017/2018".Menurut Ibrahim (Kurnia dan Ningrum, 2016:23) menyatakan bahwa: TPS (Think-Pair-Share) atau (berfikir-berpasangan-berbagi)

merupakan jenis model pembelajaran kooperatif yang dirancang untuk mempengaruhi pola interaksi peserta didik. TPS menghendaki peserta didik bekerja,saling membantu dalam kelompok kecil (2-6 anggota) dan lebih dirincikan oleh penghargaan kooperatif, dari pada penghargaan individual . Menurut Trianto (Nurul Ramadhaniy dan Nurul Hikmah Kartini 2016:17) menyatakan bahwa: "Model pembelajaran kooperatif tipe Think Pairs share merupakan model pembelajaran yang dirancang untuk mempengaruhi pola interaksi peserta didik".

Dari pendapat di atas dapat disimpulkan model pembelajaran Think Pairs Share adalah model pembelajaran kooperatif yang menekankan pola interaksi antar peserta didik sehingga terjalin cara berpikir untuk merespon suatu tugas yang dikerjakan dalam suasana variasi sebuah diskusi.

a. Langkah-Langkah Model Kooperatif tipeThink Pairs Shar
Menurut Kurnia dan Ningrum (2016:21) menyatakan bahwa: 
Langkah-langkah dari pembelajaran kooperatif tipe Think Pairs Share adalah sebagai berikut:

1) Guru mengajukan pertanyaan atau isu yang berhubungan dengan pelajaran.

2) Guru meminta peserta didik untuk berpasangan dan meminta peserta didik untuk memikirkan pertanyaan atau isu secara mandiri.

3) setiap anggota pada kelompok membandingkan jawaban atau hasil pemikiran mereka dengan mendefinisikan jawaban yang dianggappaling benar, paling meyakinkan, atau paling unik.

4) Pada tahap akhir, guru meminta kepada pasangan untuk berbagi dengan seluruh kelas tentang apa yang telah mereka bicarakan.

Menurut Ngalimun

$(2016: 237)$ menyatakan bahwa :

Langkah-langkah model pembelajaran kooperatif tipe Think Pairs Share sebagai berikut:

1) Guru menyajikan materi secara klasikal.

2) Guru memberikan persoalan kepada peserta didik.

3) Peserta didik bekerja kelompok dengan cara berpasangan sebangku-sebangku (Think Pairs).

4) Presentasi kelompok (share), kuis individual, buat skor peserta didik dan memberikan reward.

Dari pendapat di atas dapat disimpulkan bahwa langkahlangkah dalam menggunakan model pembelajaran Think Pairs Share yaitu :
Tahap 1: Guru menyajikan materi secara klasikal dan memberi sebuah pertanyaan

Tahap 2: Guru membuat kelompok secara berpasangan, memberi waktu memikirkan jawaban dari pertanyaan

Tahap 3: Presentasi kelompok

Tahap 4 :. Evaluasi

b. Kelebihan dan Kekurangan Model Think Pairs Share

Menurut Shomin (2014:314-315) menyatakan bahwa kelebihan dan kekurang dari model pembelajaran kooperatif tipe Think pairs Share adalah sebagai berikut:

Kelebihan :

1) Thin Pairs Share mudah terapkan diberbagai jenjang pendidikan dan dalam setiap kesempatan.

2) Menyediakan waktu berpikir untuk meningkatkan kualitas respons peserta didik.

3) Peserta didik menjadi lebih aktif dalam berpikir mengenai konsep dalam mata pelajaran.

4) Peserta didik lebih memahami tentang konsep tofik pelajaran selama diskusi.

5) Peserta didik dapat belajar dari peserta didik lain.

6) Setiap peserta didik dalam kelompoknya mempunyai kesempatan untuk berbagi atau menyampaikan idenya.:

1) Memberi peserta didik waktu lebih banyak untuk berfikir, menjawab, dan saling membantu satu sama lain. 
2) Meningkatkan partisipasi akan cocok untuk tugas sederhana.

3) Seorang peserta didik juga dapat belajar dari peserta didik lain serta saling menyampaikan idenya untuk didiskusikan sebelum disampaikan di depan kelas.

4) Dapat memperbaiki rasa percaya diri dan semua peserta didik diberi kesempatan untuk berpartisipasi dalam kelas.

5) Peserta didik dapat mengembangkan keterampilan berfikir dan menjawab dalam komunikasi antara satu dengan yang lain, serta bekerja saling membantu dalam kelompok kecil.

\section{Kekurangan :}

1) Peralihan dari seluruh kelas kekelompok kecil dapat menyita waktu pengajaran yang berharga. Untuk itu guru harus dapat membuat perencanaan yang seksama sehingga dapat meminimalkan jumlah waktu yang terbuang.

2) Lebih sedikit ide yang muncul.

3) Menggantungkan pada pasangan.

4) Ketidaksesuaian antara waktu yang direncanakan dengan pelaksanaannya.

Dari pendapat di atas dapat disimpulkan kelebihan dari model pembelajaran kooperatif Think Pairs Share yaitu:

1) Peserta didik menjadi lebih aktif .

2) Dapat meningkatkan cara berpikir dan merespon pertanyaan.

3) Dapat bertukar pikiran dalam kelompok berpasanganya.
4) Dapat memperbaiki rasa kurang percaya diri dari peserta didik.

Kekurangannya:

1) Munculnya ide dari peserta didik akan lebih sedikit.

2) Banyak kelompok, membuat guru susah memonitor.

3) Waktu belajar akan banyak terbuang.

\section{METODE PENELITIAN}

Penelitian ini menggunakan metode Penelitian Tindakan Kelas/PTK. Karena, penelitian ini dilakukan untuk memperbaiki proses pembelajaran dan meningkatkan hasil belajar peserta didik di kelas, khususnya pada mata pelajaran IPA dengan menggunakan model pembelajaran kooperatif tipe Think Pairs Share.

Menurut Kurniasih dan Sani (2014:2) menyatakan bahwa: "Penelitian Tindakan Kelas adalah penelitian yang dilaksanakan berdasarkan permasalahan yang dijumpai guru dalam kegiatan pembelajaran". Menurut Bahri (Bahat dan Limbun, 2015: 2) menyatakan bahwa:Penelitian Tindakan Kelas merupakan sebuah kegiatan yang dilaksanakan untuk mengamati kejadian-kejadian dalam kelas untuk memperbaiki praktek dalam pembelajaran agar lebih berkualitas dalam proses sehingga hasil belajar menjadi lebih baik.

Dari pendapat di atas, maka dapat disimpulkan bahwa Penelitian Tindakan Kelas adalah penelitian yang dilakukan dalam suatu ruang lingkup pendidikan untuk mengangkat 
masalah-masalah yang dihadapi oleh seorang guru pada saat proses pembelajaran dikelas, sehingga dengan adanya penelitian ini memperbaiki praktik dalam mengajar agar lebih berkualitas sehingga hasil belajar pun menjadi lebih baik.

Kehadiran dan peran peneliti dalam Penelitian Tindakan Kelas ini adalah sebagai peneliti sekaligus pendidik. Penelitian ini dilaksanakan di SDN- 2 Langkai Palangka Raya, Adapun subjek penelitiannya adalah peserta didik kelas V SDN- 2 Langkai Palangka Raya tahun pelajaran 2017/2018 yang berjumlah 15 orang. Dari 15 orang peserta didik tersebut, jumlah laki-laki 8 orang dan jumlah perempuan 7 orang.

\section{HASIL PENELITIAN}

Hasil observasi aktivitas guru pada siklus I dengan nilai rata-rata 2,83 dengan kategori cukup baik dan siklus II observasi aktivitas guru dengan nilai rata-rata 3,70 termasuk kategori baik. Hasil observasi aktivitas peserta didik pada siklus I dengan nilai rata-rata 2,791 dikategorikan cukup baik sedangkan pada siklus II aktivitas peserta didik dengan nilai rata-rata 3,70 termasuk kategori baik. Hal tersebut dapat dilihat dari grafik aktivitas guru dan peserta didik :

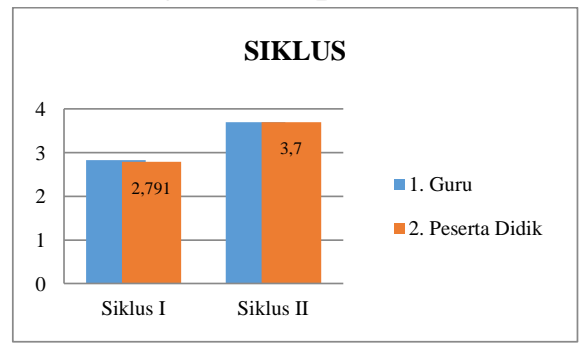

Dapat disimpulkan bahwa penggunaan model pembelajaran kooperati tipe Think pairs Share dapat digunakan dan tepat agar peserta didik aktif dalam proses pembelajaran sehingga mengalami peningkatan dalam aktivitas belajar.Nilai hasil belajar yang dimaksud disini yaitu peningkatan nilai IPA peserta didik SDN-2 Langkai Palangka Raya berikut semua hasil belajar peserta didik : Dimulai dari data awal yang diperoleh dari nilai harian peserta didik kelas $\mathrm{V}$ hanya ada 6 orang (40\%) yang mencapai KKM, selanjutnya 9 orang (60\%) tidak mencapai KKM. Mengacu pada besarnya klasikal yang telah ditentukan $85 \%$.Berdasarkan hasil belajar kelas $\mathrm{V}$ yang diperoleh pada siklus I , dari 15 orang peserta didik hanya ada 8 orang $(53,33 \%)$ dengan rata-rata 67,33 yang dapat mencapai KKM yaitu 70, sehingga dilanjutkan ke siklus II.

Berdasarkan hasil belajar yang dilakukan pada siklus II nilai peserta didik kelas $\mathrm{V}$ yaitu dengan rata-rata 80,33 dengan ketuntasan klasikal $100 \%$ dengan ini dinyatakan hasil belajar peserta didik SDN-2 Langkai mengalami peningkatan dan telah mencapai KKM yang sudah diberikan. Hal ini dapat dilihat dari grafik hasil belajar peserta didik kelas V SDN-2 Langkai 


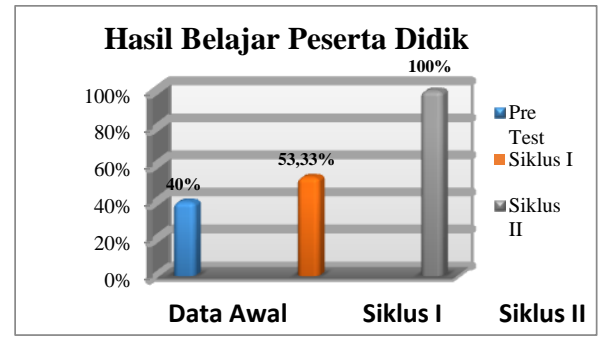

Berdasarkan analisis penelitian dapat disimpulkan bahwa penggunaan model pembelajaran kooperatif tipe Think pairs Share dapat meningkatkan hasil belajar peserta didik dalam pembelajaran IPA kelas V SDN-2 Langkai

\section{KESIMPULAN}

Berdasarkan hasil penelitian maka dapat disimpulkan bahwa:

1. Aktivitas belajar peserta didik dalam pembelajaran IPA dengan mengunakan model pembelajaran kooperatif tipe Think Pairs Share pada peserta didik kelas V SDN-2 Langkai Palangka Raya, berkategori baik .

2. Ada peningkatan hasil belajar IPA peserta didik setelah diajarkan dengan menggunakan model pembelajaran koopearatif tipe Think Pairs Share pada peserta didik kelas V SDN- 2 Langkai Palangka Raya Tahun Ajaran 2017/2018.

\section{DAFTAR PUSTAKA}

Kurnia \& Ningrum. 2016. Pengaruh Penggunaan cooperative Learning Tipe Think-PairShare (TPS) Terhadap
Hasil Belajar

Kewirausahaan Siswa

Kelas X Semester Genap

Smk Kartikatama 1 Metro

T.P 2015/2016. Jurnal

Nurul, Ramadhaniy \& Nurul Hikmah

Kartini. 2016. Upaya Meningkatkan Hasil Belajar Tematika Dengan Menerapkan Model Pembelajaran Kooperatif Tipe Think Pairs Share Kurniasih dan TPS) Pada Peserta Didik Kelas III SDN-6 Selat Hilir Kuala Kapuas Tahun Pelajaran 2014/2015: TUNAS Jurnal Pendidikan Guru Sekolah Dasar. II, 1 (Http://jurnal umpalangkaraya.ac.id/ejurnal/tun al, Hari Miggu 20 Mei 2018 pukul 13.00)

Ngalimun. 2016. Starategi dan Model pembelajaran. Yogyakarta:Aswaja Pressindo

Shomin. 2014. 68 Model Pembelajaran Inovatif dalam Kurikulum 2013. Yogyakarta:AR- RUZZ Media. 
Tunas Jurnal Pendidikan Guru Sekolah Dasar, Juni 2019, Volume 1 Nomor 2, (35-8)

ISSN : 2477-6076 